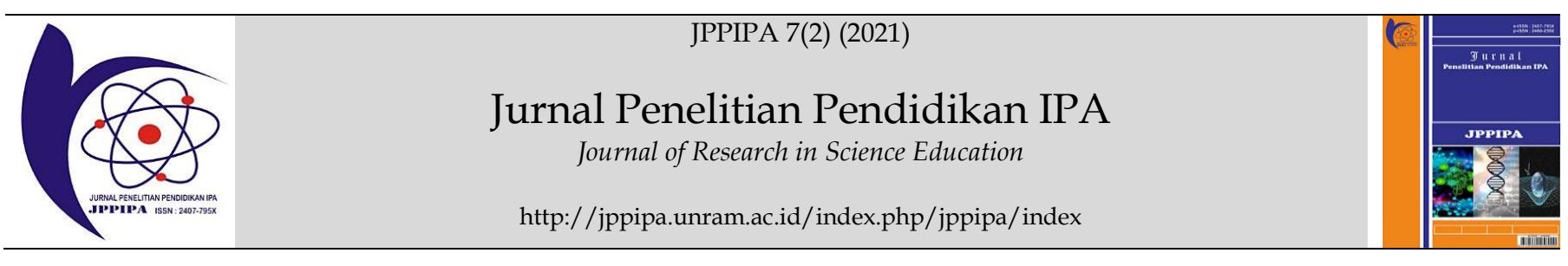

\title{
Parents' Role in Biology Learning During the Covid 19 Pandemic
}

\author{
Desi Rahmadani ${ }^{1}$, Ika Chastanti ${ }^{1 *}$, Dahrul Aman Harahap ${ }^{1}$ \\ ${ }^{1}$ Biology Education, Faculty of Teacher Training, University of Labuhanbatu, Rantauprapat, Indonesia
}

DOI: $\underline{10.29303 / \text { ippipa.v7i2.583 }}$

\section{Article Info}

Received : January $16^{\text {th }}, 2021$

Revised : March 9th, 2021

Accepted : April 1th 2021

\begin{abstract}
The role of parents in accompanying children's success while studying at home is very central, in relation to this released various guidelines for parents in accompanying their children during this pandemic which includes parenting tips to be more positive and constructive in accompanying them. Parents initially played a role in guiding basic attitudes and skills, such as religious education to obey the rules, and for good habituation, but their role became expanded, namely as a companion to academic education. The aim of this research are to explain the actual role of parents in children's learning during this pandemic and to find out what children will do if there is no role of parents in children's learning during this pandemic. This research uses purposive sampling method. In this technique the researcher determines the sumpling taking according to the research objectives, so that it is expected to answer the researcher's problems. By using a qualitative approach, the data analysis technique was carried out in a descriptive qualitative manner using the Miles Damn Huberman model. The results showed that the role of parents in learning biology during the epidemic was based on educators $(80 \%)$; Supervisor (75\%); counselors $(70 \%)$ (4) opinion on online learning $(75 \%$; the number of cities that were broadcast during the pandemic $(85 \%)$.
\end{abstract}

Keywords: Parent's Role; Online Learning; Biology.

Citation: Rahmadani, D., Chastanti, I., \& Harahap, D. (2021). Parents' Role in Biology Learning During the Covid 19 Pandemic. Jurnal Penelitian Pendidikan IPA, 7(2), 137-142. doi:https://doi.org/10.29303/jppipa.v7i2.583

\section{Introduction}

The world is currently preoccupied with the emergence of coronavirus (Covid-19). As of May 26, 2020, the virus has infected 5.623 .503 people, with 348.760 deaths and 2.393.551 deaths and 213 deaths (worldometers.info, 2020). In Indonesia, the virus first spread on March 2, 2020, and this was conveyed directly by President Joko Widodo (Nuraini, 2020), and currently has obeyed 23.165 people with the number of deaths of 1.418 people, and the number accompanying 5.877 people (covid19.go.id, 2020).

Various efforts are made by the government to break the chain of spread of this virus, including by issuing PP No. 21 of 2020 on Large-Scale Social Restrictions in order to Accelerate the Handling of Covid-19 which results in restrictions on various activities including schools. Meanwhile, Learning From
Home (BDR) activities are officially issued through the Circular Letter of the Minister of Education No. 36962/MPK. A/HK/2020 on online learning and working from home in order to prevent the spread of Corona Virus Disease (COVID-19). This policy forces teachers and students to keep working and learning from home from Kindergarten to Higher Education (kemdikbud.go.id, 2020). This policy certainly not only affects the relationship between teachers and students during BDR, but also the importance of optimizing the role of parents in the implementation of BDR. Future elementary school teachers must be able to master technology and adapt to the very fast changes in the era of the industrial revolution 4.0 (Alam et al, 2020).

The emergence of the Covid-19 pandemic in Indonesia in early March 2020 brought a change in the implementation of science learning in elementary school teacher education course (Atmojo et al, 2020). 
All schools ranging from kindergarten to high school immediately carried out the circular of the Ministry of Education without preparation and strategies for how distance learning is implemented. Since March 2020, all schools in the country have issued a decision that students should leave the school environment for an un specified period of time and the teaching and learning process becomes a Distance Learning process. According to National Education System Law No. 20 of 2003 (Sidiknas, 2003) learning is the process of interacting learners with educators and learning resources in a learning environment.

The definition of Learning according to Atwi Suparman in (Suparman, 2014) is that teachers and learners together create an environment including a set of values and beliefs that are considered important to unite the view of the reality of life. In this definition, learning still brings teachers together with learners and collaborates in creating agreements on what is important in order to in turn influence views about the realities of life. Learning activities are a series of events that affect learners in such a way that behavioral changes called learning are facilitated. Learning can be defined as a fixed influence on behavior, knowledge, and thinking skills, gained through experience.

The role of parents in accompanying children's success during home study becomes very central, in line with that WHO, (2020) released various guidelines for parents in accompanying their children during this pandemic, which includes parenting tips to be more positive and conducive in accompanying children during their activities at home. Parents initially played a role in guiding fundamental attitudes and skills, such as religious education to obey the rules, and for good habituation (Nurlaeni \& Juniarti, 2017), but its role became widespread as an academic education companion. Prabhawani (2016) stated that the implementation of education is a responsibility for parents and the surrounding community, not only the responsibility of educational institutions. Speaking of parent roles, not apart from family. Lestari, (2012) states that families are viewed from their functions, namely having the duties and functions of care, emotional and material support, and fulfillment of certain roles. In line with this, Muchtar (in Lutfatutatifah et al., 2015) stated that families are an important part of community units.

Family has an important role to play in caring for, educating, protecting and nurturing children. According to Candra et al., (2013) stated that parenting towards their children can affect the formation of the character and behavior of the child itself. If there is a parenting error, it will affect the child when he/she is an adult. In line with this, Rakhmawati, (2015) stated that childcare is an ongoing activity through the process of parent and child interaction to encourage optimal growth and development of children. The above exposure shows that during this time, the role of parents in parenting and care is more prominent, while academic education is often presented to the second party, namely the school as rosdiana explained, (2006) that the fact that most parents still feel that their obligation in educating children has been completed after entering a school institution.

In order for students to learn at home, for the safety and health of all of us, this certainly has an impact on parents, where parents must provide learning to their children at home. There's a lot of controversy about home learning. Many parents also reveal that they feel objected when the child is studying at home, because at home the child feels it is not the time to learn but they tend to like to play. Then here will be seen how the pattern of parenting while studying at home. Related to this, according to research from Khasanah (2020) at first many parents who refuse online learning for their children, because they are each with technology. But over time, parents began to receive this online defense (Ihsanuddin, 2020; Shereen et al., 2020).

\section{Method}

Research is a systematic step as an effort to solve problems (Rasimin, 2008: 4). A study was conducted using the type or method used to find the answer to the problem studied. Based on the title taken by researchers, in this study researchers used a descriptive qualitative research approach using purposive sampling techniques. In this technique, researchers determine their own sampling. In accordance with the objectives of the research, so that it is expected to answer the problem of researchers.

Data analysis techniques are performed descriptively qualitatively using the Miles damn Huberman model. This model is carried out in 3 stages: (1) Data reduction i.e. (a) summarizing direct contact data with people, events and situations at the research site, (b) encoding, (c) creating objective records, (d) making reflective records, (e) creating marginal records, (f) data storage, (g) creating memos, (h) interlocation analysis, and (i) creating temporary summaries between locations. (2) Display Data by composing narrative text. (3) Verification is the stage of drawing conclusions (Chastanti, et.al., 2019).

The statements contained in the questionnaire contain positive statements (favorable) and negative statements (infavaorable). The measurement scale of questionnaire used in this study is in the form of Likert scale model using 4 options, namely: Strongly Agree (SA), Agree (A), disagree (D), and strongly disagree (SD). The Likert scale is used to measure a person's 
attitudes, opinions, and perceptions about social phenomena (Sugiyono, 2014), hence it is considered suitable to improve students' perception of parental assistance in children's learning poses.

\section{Result and Discussion}

\section{Distribusion Parent's Role Queistionnaire}

Based on the results of research that was smeared from respondents' answers in filling in the role of parents in grade XI students at SMA N 1 Rantau Selatan, it is known that most of the respondents' answers to questions related to indicators of parenthood as educators answered agreed as many as 10 respondents (80\%) In this case it can be concluded that on the sub-variables of parenthood more choose always.

Thus, judging from the number of parents who choose it can always be said that the role of parents is very important in supporting mentoring activities towards children's learning during learning from home. Parenthood is a behavior that concerns parents in holding certain positions in family institutions and serves as a mentor, caregiver, and educator for the child and supports the social and emotional needs of the child, parents of whom participate in the child's learning, explain and provide examples and models in learning, and meet the child's learning needs, provide spiritual understanding, supervise the child's learning process, motivate and encourage the child, provide tutoring, give appreciation, provide facilities and needs of children in learning, help solve children's problems, provide teaching at the appropriate time. High family perceptions of science enable students to complete their experiments through collaboration with their families (Sha et al, 2016).

The results of this study are also in line with the results of previous research that during learning from home as an alternative to learning in the midst of the Covid-19 pandemic, in general the role of parents is as a supervisor, educator, carer, developer, and supervisor.

\section{Analysis of Parenthood as Educator}

Parents have a big role in learning children at home can be seen from $80 \%$ of parents choose to agree with the role of parents as educators at home during this pandemic. The results of interviews with parents stated that they help their children learn, although for the work of the task given by the teacher, parents rarely help the child complete the task because the child usually uses the internet to complete the task.

The role of parents in children's education is needed, because the family environment is the initial environment for a child. Parents in carrying out their role as educators need to continuously provide motivation, support, guiding, and facilitating the achievement of a good education (Fadillah, 2012). The level of parental education directly affects the continuity of children's education (Novrinda et.al., 2017). The parents stated that they were unable to assist the child in completing the task because they did not understand all the tasks given by the teacher. Therefore, some parents choose to allow their children to use internet facilities to complete tasks. Parental education will influence the mindset of the child. The higher the education of parents, the more expanding the mindset of children in education (Nilawati, 2013).

The role of parents as educators has a great task and responsibility because it is not just for the transfer of knowledge, but educating that is oriented towards the formation of children's character. Therefore, as educators, parents should be able to develop the mindset of children so that they have high abilities and personalities (Abdillah, 2019).

Guidance is a passion carried out by a person in order to provide assistance to others who are experiencing difficulties, so that the person is able to overcome themselves with full awareness. Guidance needs to be given in online learning if the child has difficulty in material matters. The absence of teachers in online learning makes parents inevitably have a dual role. That is, as a parent himself as well as a mentor and educator. In learning, often children have difficulty in terms of material understanding. Because each child's level of understanding is different and parents know better when the child is having difficulty. Seeing that, of course, parents have roles and obligations as mentors and educators. Parental guidance has a huge influence on the success of children's learning, because with the guidance of parents students can know the ways in learning so as to increase the success rate and spirit of learning of the child. In addition, children will not feel saturated because parents accompany and guide while learning. Research shows that during Covid-19, the design of family participation in education units is because most of the learning is done at home, to continue and familiarize education that involves families and for families to create a physical and non-physical environment, which is conducive to student learning, so that knowledge can be maximized (Nursetiawati et al, 2020).

\section{Analysis of Parenthood as Supervisors}

Most parents voted "Agree" with a percentage of $70 \%$. In this case it can be concluded that in the subvariables of learning assistance children prefer to always. Thus, judging from the number of parents who choose it can always be said that child learning assistance is very important in supporting children's 
learning activities during learning from home. Based on the results of data analysis that learning assistance in children in SMA N 1 Rantau Selatan is always done by parents. Evidenced by the answers of parents in SMA N 1 Rantau Selatan who prefer the answer agree. Mentoring is an activity carried out through coaching, teaching, briefing in individuals or groups. Learning is one factor that plays an important role in the formation of individual personal and behavior (Abtokhi, 2012). The term learning assistance is closely related to the process and outcomes of children's learning, because mentoring is defined as guidance that is closer to the intended subject, especially in terms of children's learning development (Retno, 2013).

The application of combination parenting pattern is an ideal parental supervision, because with a combination of foster care patterns can form both psychic and physical children (Gunawan, 2010). Parental supervision is a form of children's success by showing attention to lessons in school and emphasizing the importance of achievement for children. In the process of supervision, parents need to show a successful person so that they can be set an example by the child (Irony, 2004). There are 4 kinds of parental supervision of children, namely: (1) Authorithative Parenting (warm and firm; (2) Authoritarian Parenting; (3) Neglect Parenting; and (4) Indulgent Parenting (Kusuma, 2013). Parental supervision at home on how children learn is a must done by parents in the household. Parents should not be weak-hearted in supervising children's care but must be strong in educating them so that the learning process of children at home can provide good achievements to children in school (Anggraini and Hedrizal, 2018).

Smartphones can be used by all circles, fields and education. Smartphone use in adults is usually 1-3 hours in one use and can be used up to many times a day. Smartphone use for children has a certain time limit, if not limited it will cause addiction in children (Wiranto and Hermawan, 2017). Online learning carried out during the pandemic makes parents have to better supervise how children learn in biology learning, especially in the use of smartphones. The results of interviews with parents show that some parents only supervise their children learning or not, do not pay attention to the child learning well or instead do other activities using a smartphone. Even parents say that they do not have time to supervise how to learn because they feel tired because they work all day and do the dission of the child to be able to access online games using a smartphone.

\section{Analysis of the role of parents as child counselors}

One of the main tasks of parents is to provide motivation so that children can unleash their potential with their own efforts. Parents sometimes forget that parental motivation is useful for their children. The results of the poll analysis of $60 \%$ of parents who provide motivation or there may also be children who do not want to tell their parents. Parents are the closest figure to the child and of course the child thinks that the child knows what is going on so the child often feels the parent is one of the people who can help them when they find a problem. Encouragement can be one of the efforts of parents to provide motivation to children. Passion is the driving energy of children to do something until it is complete. In facing the development of children's learning, parents become the main figure to guide the child. The guidance should be in accordance with the awareness of the role of parents in the family, namely (1) Supervisor; (2) Guide; (3) Advisors; (4) Companion; (5) Defender; (6) The breadwinner; and (7) Role Model (Tjandrarini, 2004).

Parents need to act as counsellors who listen, study, direct, and provide correct information to children and avoid repression actions (Ginevra et.al., 2015). Parents also act as counsellors to listen to children's complaints so that parents can provide motivation so that children are more enthusiastic in their education (Tjandrarini, 2004). The results of interviews with parents stated that parents only help children in fulfilling quotas for the learning process but never ask the child about the difficulties faced by the child during the online learning process. Parents never ask the teacher to better understand the biology learning materials provided by the teacher. In addition to individual dependence on the environment, previous researchers conducted an interview study which revealed that parents are a positive factor in students' science learning. Parents provide support, academic hope, various assistance and are involved in student science education. When parents have high involvement, are carried out continuously, have an interest and hope for their children's scientific achievements, it will foster students' interest in learning science to improve students' science learning achievement (Halim et al., 2018).

Before carrying out the role of counsellor for their children, parents should first understand preparing to accept their fitrah as a parent, namely (1) Parents always put their children in a good life; (2) Parents prioritize the safety of their children; (3) Parents want their children to be vigilant; (4) Be patient with the child's bad behavior. Parents also do not close themselves to receive input from others by trying to add insight in preparing themselves to conduct counseling guidance for their children (Febrini, 2011). The role of parents in guiding children can be realized, namely (1) Parents must love their children; (2) Parents should maintain the tranquility of the home 
environment and prepare the tranquility of their children's souls; (3) Mutual respect between parents and children; (4) To realize trust; (5) Hold family gatherings and meetings. The steps that parents need to prepare as counsellors, are (1) Creating good relationships; (2) Listen wholeheartedly; (3) Recognizing the problem of the child; (4) Empathize with the child; (5) Be a good listener; (6) Do not act like a teacher; (7) Can keep secrets (Sihabudin, 2015).

\section{Conclusion}

The role of parents in biology learning in the Pandemic Period of SMA N 1 Rantau Selatan showed excellent results. The results are supported by the suitability of the results in each sub-variable, namely in the sub-variables of parenthood and child learning assistance. Mentoring is done by helping to do children's tasks, as a place to learn children, explaining and explaining the materials learned, providing a good response to learning from school. Mentoring is expected to shape the character of children who are able to do tasks that have been ordered from school, able to practice learning at home, and responsive in creating work as the implementation of learning.

\section{Acknowledgements}

Thanks Allah SWT, Lord of the word and don't forget the blessing ofmy parents. To my supervisor, who always helps me to solve it and friends who hve cheered me on.

\section{References}

Abdillah, H. (2019). The Role of Parents and Teachers as Educators in Shaping Children's Character. Mumtaz, 3(1). Hal. 219-250.

Abtokhi, A. (2012). Mother's Role in Child Learning Assistance Activities through Individual Learning-Centered Principles. Egalita, 4(2), 168177. https://doi.org/10.18860/egalita.v0i0.1993

Alam, G. M., Forhad, A. R., \& Ismail, I. A. (2020). Can education as an 'International Commodity' be the backbone or cane of a nation in the era of fourth industrial revolution? - A Comparative study. Technological Forecasting and Social Change, 159,

120184.

https://doi.org/https://doi.org/10.1016/j.techf ore.2020.12018.

Anggraini, A., \& Hendrizal, (2018).The Effect of Gadget Use on The Social Life of High School Students. Jurnal PPKn \& Hukum. 3: (1).

Atmojo, S., Muhtarom, T., \& Lukitoaji, B. (2020). The Level of Self-Regulated Learning and Self-
Awareness in Science Learning in the Covid-19 Pandemic Era. Jurnal Pendidikan IPA Indonesia, 9(4), 512-520.

doi:https://doi.org/10.15294/jpii.v9i4.25544

Candra, A. N., Sofia, A., \& Anggraini, G. F. (2013). Parenting Style in Early Childhood Ariya. Journal of Chemical Information and Modeling, 53(9), $\quad$ 16891699.https://doi.org/10.1017/CBO978110741532 4.004

Chastanti, Maharani Gultom, Novi Fitriandika Sari. (2019). Analysis of Internet Usage of Friendly/Communicative Characters in Biology Learning. Jurnal Pelita Pendidikan. 7(4). 178 - 184

Covid19.go.id. (2020). Data of Distribution. Covid19.Go.Id. https:// covid19.go.id/

Fadhillah, M. (2012). Desain Pembelajaran PAUD. Yogyakarta: Ar-Ruzz Media. [Indonesian]

Febrini, Deni. 2011. Bimbingan Konseling. Yogyakarta: Teras

Gunawan. W. (2010). Kebut Sehari Menjadi Master PHP. Yogyakarta: Genius. [Indonesian]

Halim, L., Abd Rahman, N., Zamri, R., \& Mohtar, L. (2018). The roles of parents in cultivating children's interest towards science learning and careers. Kasetsart Journal of Social Sciences, 39(2), 190-196.

https://doi.org/https://doi.org/10.1016/j.kjss.2 017.05 .001

Irony, T. (2004). Bunga Rampai Sosiologi Keluarga. Jakarta: Yayasan Obor. [Indonesian]

Ministry of Education and Culture. (2017). Being a Great Parent For Families with Early Childhood. In My Hero. 98(25). Ministry of Education and Culture. $\quad$ http://118.98.227.114/glnsite/wpcontent/uploads/2017/09/Juknis_PAUD.pdf

Kusuma. R. 2013. Macam-macam Pengawasan Orangtua Terhadap Anak. Bandung: Remaja Rosdakarya. [Indonesian]

Lestari, S. (2012). Psikologi keluarga : penanaman nilai dan penanganan konflik dalam keluarga (2nd ed.). Kencana. [Indonesian]

Lutfatutatifah., Adriany, V., \& FaizahRomadona, N. (2015). Parenting Patterns of Early Childhood In Kampung Adat Benda Kerep Cirebon City. Jurnal Pendidikan Serantau, 1(1), 1-226.

Novrinda., Nina, K., \& Yulidesni. (2017). Parental War in Early Childhood Education Reviewed from Educational Background. Jurnal Potensia PG PAUD FKIPUNIB. 2 (1). 29-44

Nurlaeni, N., \& Juniarti, Y. (2017). The Role of Parents in Developing Language Skills In Children Aged 4-6 Years. Jurnal Pelita PAUD. https://doi.org/10.33222/pelitapaud.v2i1.196 
Nursetiawati, S,. Josua D.P,. Atmanto, D,. Oktaviani, F., Fardani, A.L. (2020). Science Education in The Family Environment With the Experimental Method Of Facial Cosmetics Plant Fertilization In The Covid-19 Pandemic Era. Jurnal Pendidikan Ipa Indonesia, 9 (4), 561-573

Prabhawani, S. W. (2016). Parents' Involvement in the School Program at Khalifah Rasimin Kindergarten. Pendidikan Guru PAUD S-1, 2(5), 205-218. Retrieved from http://journal.student.uny.ac.id/ojs/index.php Lpgpaud/article/view/1217

Rasimin. (2008). Metodologi Penelitian: Pendekatan Paktis Kualitatif. Yogyakarta: Mitra Cendekia [Indonesian]

Rakhmawati, I. (2015). The Role of The Family in Child Care. Jurnal Bimbingan Konseling Islam, 6(1). https:// doi.org/10.21043/kr.v6i1.1037

Retno, A. (2013). The Relationship of Intensity of Parent Learning Assistance with the Quality of Student Learning Outcomes in Ra Al-Islam Mangunsari 02 Semarang Year Lesson 2011/2012. Indonesian Journal of Early Childhood Education Studies, 2(2), 43-49. https:// doi.org/10.15294/ijeces.v2i2.9240

Rosdiana, A. (2006). Parental Participation in Early Childhood Education: Survey on Playing Groups In Yogyakarta City. Jurnal Ilmiah VISI, 1(2), 6272.

https://doi.org/https://doi.org/10.21009/JIV.0 $\underline{102.10}$

Sha, L., Schunn, C., Bathgate, M., \& Ben Eliyahu, A. (2016). Families support their children's success in science learning by influencing interest and self-efficacy. Journal of Research in Science Teaching, 53 (3), 450-472

Sihabudin, M. (2015). The Role of Parents in Student Counseling Guidance. Jurnal Kependidikan. 3 (2). Hal. 123-137.

Sugiyono. (2014). Metode Penelitian Kuantitatif Kualitatif dan RED. Bandung: CV Alfabeta. [Indonesian]

Wiranto, S.A., Hermawan, M.A. (2017). The Role of Parents in Child Supervision in Smartphone Use. National Seminar and Call for Paper "Membangun Sinergitas Keluarga dan Sekolah Menuju PAUD Berkualitas. Wirobrajan Yogyakarta. Pendidikan Guru PAUD S-1.

WHO. (2020). Coronavirus disease (COVID-19) advice for the public: Advocacy. Www.Who.Int. https://www.who.int/emergencies/diseases/n ovel-coronavirus-2019/advice-forpublic/healthy-parenting 